\title{
DA FUNDAÇÃO DO ESTADO A BUSCA POR JUSTIÇA: A TEORIA CONTRATUAL E NEOCONTRATUAL
}

Flávio Pansieri ${ }^{1}$

\section{Resumo}

O presente artigo tem por escopo relacionar as teorias de Thomas Hobbes, John Locke e John Rawls. Separados por séculos, tais autores têm em comum o fato de serem incluídos na tradição do contrato social. $\mathrm{O}$ contratualismo, em sua vertente clássica e contemporânea, pretende legitimar uma determinada leitura do Estado, servindo como um recurso de justificação a esta teoria. Compartilhando a essência da idéia contratual, o intuito é mostrar as minúcias de cada um destes autores a partir de seu ponto de vista histórico, político e jurídico. Para tanto, será analisada a mais notável obra de cada autor (Leviatã. Dois tratados sobre o governo e Uma Teoria da Justiça), de modo a contribuir com a pesquisa jurídica e filosófica.

Palavras-chave: Contratualismo. Neocontratualismo. Leviatã. Dois Tratados Sobre o Governo. Uma Teoria da Justiça.

\section{INTRODUÇÃO: A NOÇÃO GERAL ÍNSITA AO CONTRATO SOCIAL}

A passagem da Idade Média para a Idade Moderna é, via de regra, compreendida como a transição de um ideal de vida centrado em Deus e as descobertas científicas e sociais que colocaram os seres humanos novamente no comando de seus próprios destinos. No mundo político, a secularização e o ressurgimento da esfera pública que eclode no Estado liberal provocaram intensa revolução no modo de ser das sociedades.

A análise acerca do limiar do Estado tem como ponto de passagem os autores do período denominado contratualismo. Nesta corrente contratual inicial, pensadores como Thomas Hobbes e John Locke declinaram de análises centradas na figura divina e passaram a repensar o espaço público e as suas instituições fundamentais para a formação de uma sociedade secular e para a colmatação das inúmeras debilidades sociais no momento em que a política se respaldava no cetro real. Distintos entre si em diversos pontos, eles comungavam de uma mesma sintaxe e de uma mesma estrutura conceitual - a passagem do estado de natureza para o estado social por meio de um contrato social - de modo a alicerçar o poder em alguma forma de consenso.

O estado de natureza, de modo geral, é uma abstração necessária. Adota-se a perspectiva de que ele é

\footnotetext{
${ }^{1}$ Doutor em Direito pela Universidade Federal de Santa Catarina. Mestre em Direito pela Universidade de São Paulo. Presidente do Conselho Fundador da Academia Brasileira de Direito Constitucional - ABDConst. Professor de Direito Constitucional da Pontifícia Universidade Católica do Paraná, campus de Curitiba. Advogado. E-mail: pansieri@pansierikozikoski.com.
} 
uma hipótese lógica a fim de destacar a idéia racional ou jurídica do Estado e de colocar o fundamento de legitimidade política na construção de uma autoridade validada pelo consenso popular, seja ele expresso ou tácito. Não sendo necessária a comprovação de sua existência, todavia, ele se torna um meio para justificar soluções. Como um periscópio voltado para o passado, a concepção do estado de natureza varia, pois o diagnóstico de cada pensador acerca da sua sociedade também é diferente. Assim, o estado de natureza legitima sua percepção de seu presente e as mudanças necessárias para a reforma social orquestrada pelo pensador político.

No contratualismo clássico subjaz uma análise que, nos termos de Norberto Bobbio (1998, p. 272), "predomina o elemento jurídico como categoria essencial da sintaxe explicativa", na qual o direito é o caminho de racionalização das relações sociais ou de sublimação jurídica da força. Tal afirmação se justifica pela preponderância da idéia de direito natural para estes autores. Assim, o escopo do direito natural estava na legitimação do Estado travada em face do poder soberano, tanto pela legitimidade de sua legislação como pelo monopólio da força coativa.

Neste sentido, compulsar a obra de tais autores pressupõe se lançar em seus períodos históricos, vislumbrar os seus problemas cotidianos da inexistência de uma esfera pública consolidada. Qual instrumento jurídico mais sólido e digno de confiança que um contrato para encarnar a metáfora de uma nova sociedade? Todo contrato pressupõe um acordo entre as partes contratantes. Não se trata, portanto, de uma forma de aquisição do poder político por imposição, mas de um meio com características republicanas e pré-constitucionais para seu estabelecimento, ainda que alguns autores, como Thomas Hobbes, vislumbrassem um poder soberano na condução do Estado.

Ainda a respeito do contrato, oportuno salientar que, inversamente, esta contratação não deve se pautar em cláusulas leoninas, mas por salutar modus operandi de uma obrigação na qual haverá necessariamente a limitação de alguns direitos em favor da conquista de outros. Nesta sociedade pós-medievo, verifica-se um aparato jurídico estatuído e legado através das gerações - como a influência do direito romano e germânico -, bem como a tradição da filosofia política grega redescoberta na Idade Média como padrão de um modo distinto de fazer a política.

Assim, partindo-se destas premissas elementares, elegeu-se como foco investigativo a análise contratual de Thomas Hobbes, John Locke e John Rawls a partir de suas obras mais notáveis, respectivamente, Leviatã, Dois tratados sobre o governo e Uma teoria da justiça. A partir deste marco teórico, investigar-se-á como cada um estatui as vantagens a serem adquiridas pela celebração do pacto social, quais direitos serão entregues para a sua elaboração, a possibilidade de retroceder ao status quo e outras indagações que perpassam a este modo de pensar o político. Em suma, o desiderato deste artigo é investigar algumas minúcias do contrato social nestes autores. Frise-se que não há o intento em se defender uma noção evolutiva do contrato social, mas compreender os diferentes pontos de vistas respaldados pelos momentos históricos vividos por cada um destes autores. 


\section{THOMAS HOBBES: LIBERDADE E OBEDIÊNCIA AO PACTO SOBERANO}

\section{Antecedentes históricos}

Tradicionalmente, Thomas Hobbes é o primeiro pensador a enunciar a teoria do pacto celebrado entre todos para a criação de uma esfera política secularizada. Nascido em 1588, Hobbes obteve perspectivas políticas abrangentes como expectador da ebulição política, jurídica e econômica pela qual passava a Inglaterra. Na seara política, o país iniciou o século XVII como monarquia absolutista. O governo pacífico exercido pela Dinastia dos Tudor, um verdadeiro oásis após um período beligerante de conflitos externos - como a Batalha de Bannockburn contra a Escócia, em 1314, e a Guerra dos Cem Anos contra a França, de 1337 a 1453 - e internos - como a Guerra das Rosas, ocorrida entre 1455 e 1485 -, chegou ao fim em 1603 quando a Casa dos Stuart assumiu a condução do governo até 1689. Neste momento, Jaime II é deposto por Guilherme III na conhecida Revolução Gloriosa, a partir do qual a Inglaterra assume a monarquia parlamentar constitucional.

Neste ínterim, o país ainda se viu assolado por uma Guerra Civil (1641-1649) fruto das disputas entre Rei e Parlamento. No âmbito econômico, neste mesmo período a Inglaterra enfrentava a Espanha na Guerra Anglo-Espanhola (1585-1604) em virtude, principalmente, da cisão inglesa com o catolicismo ante a Reforma Anglicana, comandada por Henrique VII em 1534. Esta guerra viria a espoliar ambas as nações, tendo seu fim com a assinatura do Tratado de Londres. Por outro lado, o século XVII é o marco do poderio naval inglês, fator essencial para a sua consolidação junto às colônias na América do Norte e para a ampla acumulação de riquezas que engendraria a Revolução Industrial do século seguinte.

Além disto, o século XVII na Inglaterra também possui grande notoriedade jurídica pela edição de dois documentos normativos fundamentais na consolidação da garantia de direitos e no controle das prerrogativas de poder que eclodiriam na construção do ideal constitucional dos séculos seguintes: A Petição de Direitos de 1628 e a Declaração de Direitos de 1689. Pressionado para obter recursos financeiros e dar seguimento às investidas militares da Guerra dos Trinta Anos, o Parlamento editou A Petição de 1628 em face dos interesses de Carlos I. As principais conquistas deste documento se relacionam às liberdades conferidas aos cidadãos e ao próprio Parlamento em face das amplas prerrogativas do cetro real. Seus principais enunciados são: que nenhum homem livre pudesse ser preso ou espoliado de seus bens, salvo por sentença de seus pares; que nenhum tributo fosse criado ou cobrado pelo Rei ou herdeiros sem a existência de prévio consentimento de setores da sociedade, tais como o dos arcebispos, condes, barões, cavaleiros, entre outros; que ninguém fosse condenado à morte senão em virtude dos costumes ou das leis preestabelecidas no reino; e ainda que nenhum inglês fosse expulso de suas terras ou, detido, preso, deserdado ou morto, sem lhe possibilitar o direito de defesa através de um processo com regras adequadas para tal finalidade. 
Já a Declaração de Direitos de 1689 foi estabelecida como corolário da Revolução Gloriosa. A finalidade da Declaração é a mesma da Petição de Direitos, isto e, seu escopo é a ampliação das liberdades frente ao Rei, o que permitiu que os teóricos do Direito a identificassem como fundamento para a transição entre o absolutismo e a monarquia parlamentar e servisse de referência emblemática para a Constituição dos Estados Unidos da América de 1787 e para a Declaração dos Direitos do Homem e do Cidadão de 1789. A Declaração de Direito de 1689 assegurou a liberdade tanto na eleição dos parlamentares como no uso da palavra nos debates e procedimentos concernentes aos trabalhos Legislativos, além de exigir a convocação periódica do Parlamento de modo a impedir sua dissolução ou dirimir sua importância nos assuntos políticos ingleses. Visou limitar ainda mais a prerrogativa real ao tornar obrigatória a consulta ao Parlamento antes da suspensão ou execução de uma lei, além de tornar obrigatória a legislação do reino, inclusive ao monarca, e proibir a manutenção de forças armadas permanentes em tempos pacíficos sem autorização parlamentar.

Hobbes foi testemunha de grande parte destes acontecimentos e seu pensamento foi influenciado por eles. Em 1651, em um momento de experiência pessoal, quando já contava com mais de sessenta anos, publica suas duas obras mais notáveis - De Cive e Leviatã. Segundo Marcelo Bueno Martins, Hobbes descrevera que a situação inglesa quando de seu nascimento era de medo ante a possível invasão da Espanha na Guerra AngloEspanhola. Em suas palavras, "minha mãe pariu gêmeos, eu e o medo" (MARTINS, 2010, p. 1-2). E o medo ainda o perseguiria por diversos outros momentos, como durante a revolução científica de Galileu Galilei que estremecera o mundo cristão e colocou a todos em estado de alerta - em meio a "irracional" Guerra Civil inglesa, em 1640 quando o Parlamento hostil ao autoritarismo fez o pensador de Malmesbury fugir para a França -, e ainda na ocasião de seu retorno forçado à Inglaterra, onze anos depois, quando publicara o Leviatã e se viu obrigado a sair da França por receio de ser perseguido pelo catolicismo.

\section{A constituição do Leviatã}

Hobbes inaugura uma tradição de pensamento cujo foco se bifurca no momento anterior e posterior à formação do pacto social para a criação do Estado. A análise proposta na obra Leviatã ocorre também nesta dicotomia entre estado natural e estado social. O chamado estado de natureza humano, aspecto corrente entre os autores do contratualismo, destaca-se no pensamento hobbesiano pelo seu profundo teor antropológico. $\mathrm{O}$ autor observa que o ser humano individual ainda neste estado se caracteriza por ser pura potência que se move pelo desejo; por conseguinte, verifica-se um aspecto maléfico na liberdade irrefreada: os homens, movidos por paixões como a inveja e sobretudo pelo temor da morte, abusam de sua liberdade. Tal abuso, no seio da sociedade, tem o condão de produzir uma guerra. 
A maneira pela qual o excesso de liberdade gera um conflito de todos contra todos é expressa em uma fórmula permeada pelo realismo hobbesiano. Para o autor, a natureza constituiu o ser humano de maneira parecida tanto física como mentalmente. Biologicamente não é passível a alegação de vantagens naturais a determinados indivíduos: mesmo o mais fraco dos homens pode deter a capacidade e a potência de afligir o mais vigoroso, usando da astúcia própria ou se associando com outros para este fim. Esta constatação tem o efeito de concluir que não há grandes vantagens entre os indivíduos e nenhum deles pode se sentir completamente seguro.

Além de muito semelhantes em sua fisiologia, os seres humanos ainda cultivam a mesma esperança de atingir a determinados bens. Nas palavras de Hobbes (1997, p. 108), "se dois homens desejam a mesma coisa, ao mesmo tempo que é impossível ela ser gozada por ambos, eles tornam-se inimigos". Ou seja, o problema vislumbrado pelo autor é que as pessoas tendem a desejar as mesmas coisas que são escassas: não havendo bens em igual medida para todos, abre-se a possibilidade da ganância e da cobiça. $\mathrm{O}$ efeito imediato é o estabelecimento de relações sociais pautadas pelo conflito e pela inimizade.

A regra de ouro neste estado de competição e insegurança é o ataque, ou nas palavras do pensador, a antecipação. Ou seja, através da força ou da astúcia, o objetivo é angariar poder ao subjugar o maior número de pessoas pelo maior tempo possível de modo a eliminar qualquer ameaça. A partir deste olhar antropológico, Hobbes esquadrinha a relação própria no estado de natureza que é marcada pela guerra de todos os homens contra todos os homens. Segundo o autor, a discórdia entre os homens se dá por três causas principais: a competição, causada pelo desejo de lucro, a desconfiança, perpetrada pela busca por segurança, e a glória, ao se pretender boa reputação. A violência será validada pelos avarentos para se tornarem senhores dos outros, será referendada pelo inseguro para a sua autodefesa, e pelo presunçoso por ninharias, ou seja, qualquer ato que revele desprezo pela sua família, amigos, pátria ou contra o seu nome (HOBBES, 1997, p. 108-109).

Tal é o estado de guerra entre os homens, que são lobos que vicejam entre si e constituem a sociedade. Hobbes, por observar a desordem política de seu tempo, tem um olhar bastante fatalista deste estado. Segundo ele, a conseqüência natural da guerra é o desaparecimento da sociedade em todos os seus níveis. Não será possível o desenvolvimento industrial já que incerto é o seu fruto; por via de conseqüência, não haverá cultivo da terra, navegação ou mercadorias importadas, nem tampouco construções confortáveis e maquinários para lhes erigir. Diante deste caos, os últimos bens a se extinguirem são o conhecimento, o tempo, as artes e as letras. Esta condição mundana de destruição se refletirá em dado momento na vida dos homens, que será "solitária, pobre, sórdida, embrutecida e curta" (HOBBES, 1997, p. 109).

Assim:

Desta guerra de todos os homens contra todos os homens também isto é consequêencia: que nada pode ser injusto. As noções de bem e de mal, de justiça e injustiça não podem aí ter lugar. Onde não há poder comum não há lei e onde não há lei não há injustiça. Na guerra, a força e a fraude são duas virtudes cardeais (HOBBES, 1997, p. 110). 
Neste cenário quase apocalíptico construído por Hobbes, a passagem para o estado social é condição necessária para a preservação da vida. Consoante comentário de François Châtelet, "o estado de natureza é, ao mesmo tempo e contraditoriamente, plena liberdade - aquém de todo o direito - e terror constante: ele é inviável (CHÂTELET et al, 2009, p. 48). Desta forma, o estado de natureza é oposto ao estado de sociedade; Hobbes se afasta de Aristóteles ao enunciar que a criação da sociedade é artifício humano, jamais conseqüência natural. A centelha que conduz a combustão da guerra ocorre quando os homens passam a conviver e, assim, necessariamente se iniciarão os choques de personalidade, haja vista cada qual ter desejos particulares. No afã de satisfazer o próprio querer tendo em vista bens semelhantes, conforme Hobbes salienta, o ser humano resvala na liberdade alheia, e "enquanto cada homem detiver seu direito de fazer tudo quanto queira todos os homens se encontrarão numa condição de guerra” (HOBBES, 1997, p. 114).

O traço que torna possível a construção da sociedade, portanto, é a limitação do direito natural plasmado na liberdade dos indivíduos. O filósofo lembra que não há espírito de justiça no estado natural em virtude da inexistência de regras. Diante dos famigerados perigos proporcionados pelos outros, a liberdade é uma prerrogativa para preservação do direito natural da vida e ao mesmo tempo, de modo ambivalente, a causa da guerra entre os homens em seu estado de natureza.

\section{A celebração do pacto para a constituição do Leviatã}

A transição do estado de natureza para o estado civil no pensamento de Thomas Hobbes é essencial para o desenvolvimento humano e aperfeiçoamento da vida em todas as suas conjecturas. Neste sentido, ele lista três princípios naturais que moverão os seres humanos no sentido de estabelecer um pacto fundado na renúncia de parte de suas liberdades pessoais para a formação de um soberano que proporcione segurança com base no controle de todos: o primeiro desejo dos homens é a busca da paz, a perfeita antítese da alcatéia humana presente no estado natural. Este anseio será alcançado apenas quando todos, de comum acordo, concordarem em despojar de "seu direito sobre todas as coisas" (MORRISON, 2006, p. 109).

O princípio seguinte trata de uma decisão, na qual os homens devem consentir em outorgar a sua ampla liberdade, porém em estrita similitude. Em outros termos, cada pessoa renunciará à mesma parcela de prerrogativas para que a constituição de uma soberania comum que guarnecerá a todos sob o pálio da lei comum². Subjaz neste aspecto uma questão de segurança: Hobbes adverte que "se os outros homens não renunciarem a seu direito, assim como ele próprio, nesse caso não há razão para que alguém se prive do seu, pois isso equivaleria a

\footnotetext{
${ }^{2}$ Sob esta perspectiva, Natalia Maruyama comenta que "a renúncia que um homem faz de seu direito, renúncia implicada no pacto instaurador do poder político, é deixar de pretender negar ao outro esse mesmo direito; em outras palavras, é reconhecer que todos os outros têm também um direito sobre as mesmas coisas que ele próprio. Só assim é possível acordo, justiça, partilha" (MARUYAMA, 2009, p. 52).
} 
oferecer-se como presa e não a dispor-se para a paz" (HOBBES, 1997, p. 114).

Tal renúncia de direitos ocorreria mediante um contrato comutativo e, vinculado a ele, está o último princípio: o estabelecimento do pacto e o seu devido cumprimento. A noção de justo e injusto na filosofia hobbesiana se vincula a observância ou não do acordo feito entre todos, e sua conservação ocorrerá a partir de regras jurídicas cujo poder coercitivo seja "capaz de obrigar igualmente os homens ao cumprimento de seus pactos mediante o terror de algum castigo, que seja superior ao benefício que esperam tirar do rompimento do pacto" (HOBBES, 1997, p. 123).

Assim, motivados pela guerra irretorquível, os homens celebram o pacto criador e legitimador do Leviatã, isto é, o Estado soberano. Na realidade, Hobbes está dizendo ser imprescindível a existência da soberania absoluta para pôr fim à guerra ao fazer uso da lei e da força de modo a coagir à sua observância. E como lhe constituir? Tal compreensão hobbesiana é motivada, segundo Wayne Morrison (2006, p. 99-101), a partir de uma epifania do autor ao analisar a relação entre Deus e os homens. Citando textos evangélicos, ele percebe que Deus está na base da obediência pelo fato de seu poder ser irresistível, conduzindo o homem a um estado de constante temor reverencial. Em termos técnicos, Morrison comenta que Hobbes descobre a essência que liga o homem à religião é o mana, isto é, medo de poder.

Nesta medida, assim como Prometeu rouba o fogo de Zeus para lançar ao mundo dos mortais, o Leviatã hobbesiano se apropria deste poder que dá origem ao temor, retirando de Deus a autoridade que the cabia no medievo para guarnecer a soberania absoluta do Estado moderno. Em seu livro específico sobre Thomas Hobbes, Norberto Bobbio (1991, p. 26) discorre que a escassez de poder que resulta em anarquia é o maior anátema hobbesiano e o que legitima a construção da autoridade suprema do Leviatã. Em suas palavras:

Hobbes é obcecado pela idéia da dissolução da autoridade, pela desordem que resulta da liberdade de discordar sobre o justo e o injusto, pela desagregação da unidade do poder, destinada a ocorrer quando se começa a defender a idéia de que o poder deve ser limitado, ou, numa palavra, obcecado pela anarquia que é o retorno do homem ao estado de natureza. O mal que ele mais teme - e contra o qual se sente chamado a erigir o supremo e insuperável dique de seu sistema filosófico - não é a opressão que deriva do excesso de poder, mas a insegurança que resulta, ao contrário, da escassez de poder.

É notável a doutrina hobbesiana de que "os pactos sem a espada não passam de palavras" e isto se justifica na medida em que "se não for instituído um poder suficientemente grande para nossa segurança, cada um confiará, e poderá legitimamente confiar, apenas em sua própria força e capacidade, como proteção contra todos os outros" (HOBBES, 1997, p. 141). O poder soberano, exercido por um homem ou uma assembléia, é resultado da combinação do poder de todos os contratantes, mas é pleno e independente no cumprimento de sua função.

Desde a publicação de Leviatã, Hobbes tem sido classificado como um arauto do absolutismo despótico ao defender a soberania ilimitada. Contudo, há dois fatores que desmistificam este argumento: o primeiro é que o estado soberano se organizará pelo império do Direito; e também, a despeito de a soberania ser absoluta, o autor 
considera que há direitos individuais invioláveis, o que legitima até mesmo a desobediência aos mandamentos da lei civil.

Acerca da questão jurídica, abstrai-se que, constituído o soberano que guiará o Estado e protegerá a inviolabilidade de seus súditos ${ }^{3}$, este usará de suas prerrogativas para ordenar a esfera política se valendo da edição de leis. Cabe à vontade do soberano determinar quais são os interesses da sociedade e legislar neste sentido. A este respeito, estaria Hobbes concedendo uma autorização despótico-draconiana a seu governante, nos moldes das monarquias autoritárias européias do período pós-renascimento? Tal afirmação não é escorreita, uma vez que a função do soberano é criar o aparato mínimo para o bom desenvolvimento das relações dos indivíduos e também garantir a existência da justiça. Algumas questões são pacíficas em seu pensamento: a lei é uma ordem, emanada exclusivamente do Estado e do soberano, seja uma pessoa ou uma assembléia, e não se aplica a todos - são considerados inimputáveis os débeis naturais, as crianças, os loucos e os animais.

Wayne Morrison destaca interessantes análises hobbesianas do papel da lei. Segundo ele, Hobbes antecipa em quase quatro séculos a discussão do realismo jurídico norte-americano ${ }^{4}$ que possibilita ao magistrado operar a interpretação da legislação - "todas as leis, escritas ou não, precisam de interpretação" (HOBBES, 1997, p. 213) - e ainda as proposições de Hans Kelsen sobre a natureza das leis penais que têm como destinatários as autoridades que farão funcionar a máquina estatal. Oportuno ainda destacar que o direito natural se torna obrigatório após a constituição do Estado, que mantém a existência das leis naturais - não escritas - e as leis civis normas escritas. Estas últimas, que adquirem vigência tão somente a partir da validade de sua sistematização e publicação, devem representar a vontade do soberano. Isto não significa que a legislação se desvirtuará em expressão do capricho de sua autoridade emanante, vez que o soberano fornecerá as bases "cuja criação permite uma nova o desenvolvimento de uma nova forma de ordem social" que se pauta na segurança do Estado de Direito; e os súditos, assim, poderão firmar contratos, porão em prática seus desejos de progresso, de recompensa e de bens (MORRISON, 2006, p. 114).

O segundo fator é a defesa dos direitos dos súditos, dentre eles a liberdade, o principal direito natural pertencente aos homens. Na formação do Estado, Hobbes explica que o homem nega a si mesmo determinadas liberdades, renunciando a sua prática em favor da constituição do pacto para a formação da vontade soberana una e última. Em outras palavras, a liberdade ilimitada do estado natural foi contida para a formação da sociedade. Assim, os homens são livres para agir em tudo aquilo que a lei civil do Estado não proibiu, bem como no locus em

\footnotetext{
${ }^{3}$ Súdito é o termo que Hobbes utiliza para denominar os cidadãos.

${ }^{4}$ Os autores do realismo jurídico nos Estados Unidos desenvolveram uma teoria na qual enunciavam que a reflexão jurídica seria um meio hábil e necessário para resolver os problemas do cotidiano, tendo como principais autores Charles Sanders Peirce, William James, John Dewey e Oliver Wendell Holmes, dentre vários outros. Segundo Hobbes, "A interpretação das leis de natureza é a sentença do juiz constituído pela autoridade soberana, para ouvir e determinar as controvérsias que dela dependem, e consiste na aplicação da lei ao caso em questão" (HOBBES, 1997, p. 214).
} 
que se permitiu a sua ação e se disciplinou a forma correta da prática do ato (como a possibilidade de realizar negócios por meio de contratos).

Existem direitos dos súditos considerados intransferíveis inclusive se determinados pelo próprio poder soberano uma vez que infringe o direito natural dos súditos. Hobbes lista alguns deles. Ninguém estará autorizado a renunciar ao próprio direito de resistência contra um ataque violento que possa pôr em risco a integridade física ou até mesmo a própria vida. No mesmo sentido, ninguém pode dispor de qualquer súdito, dando ordens para que ponha fim a sua vida. Hobbes cita o exemplo dos militares, que naturalmente colocam a vida em risco para cumprir missões em favor da coletividade e do Estado. Neste caso, não será considerada traição quando um soldado se recusar a combater por medo - ainda que o soberano em seguida possa the condenar a morte! $!^{5}$

Da mesma sorte, nenhum súdito tem a liberdade de resistir ao poder da justiça do Estado, seja culpado ou inocente. Caso um indivíduo tenha cometido um crime que lhe custe a vida, Hobbes considera ser legítimo que ele se levante contra todos, ainda que culpado, pois a proteção à sua vida é o direito natural mais fundamental e que legitimou a criação do Leviatã. Da mesma forma, ninguém também estará obrigado a confessar um crime se estiver sendo interrogado, não sendo razoável a ninguém a obrigatoriedade à disposição de suas principais prerrogativas (liberdade e vida). E por fim, o autor reafirma a ampla liberdade de ação ou omissão quando a lei silencia à prática ou abstenção de determinados atos (HOBBES, 1997, p. 115 e 175-177).

Todas essas prerrogativas são tidas por Hobbes como direitos naturais e não podem ser relativizados. Em algumas situações, haverá claro contrassenso entre a lei civil e a natural, mas ambas constituem o arcabouço legal do Estado, devendo ser interpretadas de modo harmônico. Todavia, ainda que tenha violado a lei civil, o súdito não perde as suas prerrogativas naturais, como por exemplo, dispor dos meios necessários para a salvaguarda de sua vida ou segurança.

Nos termos de François Châtelet:

Apesar de seu rigor e de sua extensão, o pacto que o institui (o Estado) não poderia fazer com que os indivíduos perdessem o que pertence à natureza deles. Se é verdade que esses só têm as liberdades de conduta autorizadas pelo Estado, também é verdade que - quaisquer que sejam as ordens do soberano - eles alienam sua liberdade de pensamento, renunciam à defesa do seu próprio corpo e aceitam "fazer mal a si mesmos" ou fazer mal a outros somente se julgarem que isso é útil, como por exemplo, na guerra (CHÂTELET et al, 2009, p. 49).

Opor-se ao Estado na defesa dos direitos naturais é lógico e demonstra como Hobbes tem coerência com a extensão de seu pensamento: a violação de um direito faz com que homens em estado social sofram males semelhantes aos do estado de natureza, mas agora ninguém mais conta com todos os meios para agir livremente em sua própria defesa como no estado natural. Por esta razão, embora os súditos não podem desfazer o pacto livremente, sua obrigação para com o soberano se estende até o ponto em que ele é capaz de garantir a segurança

\footnotetext{
${ }^{5}$ Este homicídio estaria acobertado em razão da recusa do soldado comprometer e pôr em risco a vida dos súditos, causa principal da existência do Estado.
} 
de todos $^{6}$. Se tornado prisioneiro de guerra, por exemplo, um cidadão detém a liberdade de cometer atos contrários aos mandamentos civis - por exemplo, tentar fugir a enfrentar os inimigos do seu Estado -, vez que realizado para a guarida de sua existência. Da mesma forma que um prisioneiro de guerra estrangeiro pode e deve tentar se libertar e fugir, haja vista não compartilhar da mesma lei civil do local onde está aprisionado.

Todos estes elementos da teoria política de Thomas Hobbes se tornaram marcantes, legando-o como figura necessária para a compreensão da jusfilosofia do século XVII. A despeito de conceber um poder absoluto, com todas as nuances comentadas, tal potência derivaria do pacto celebrado e não brotaria de uma figura divina, $\mathrm{o}$ que marca a transição definitiva com o pensamento do medievo. O soberano de Hobbes é a figura central no Estado. É dele, e não de um corpo Legislativo, que brota a lei que organizará o Direito e a justiça. A partir do império da lei, cuja autoridade brota da espada coercitiva do soberano, a liberdade adquire limites e fornece a condição necessária para a vida segura na sociedade.

\section{A LUTA CONTRA O ABSOLUTISMO EM JOHN LOCKE}

John Locke é um dos mais expoentes pensadores do período moderno, inserindo-se num contexto cujas reflexões políticas e jurídicas foram influenciadas pelo contratualismo, pelo jusnaturalismo e pelo racionalismo cartesiano. No contexto político, Locke viveu em um momento semelhante ao de Thomas Hobbes, coincidindo a transição entre o legado do medievo e o empenho pela dessacralização do poder político. Conforme já exposto, o contratualismo compreende as teorias políticas que vêem a origem da sociedade e o fundamento do poder político num acordo, tácito ou expresso, que assinala o fim do estado natural e o início do estado social e político. Locke incorpora os contornos desta tradição, mantendo-se fiel aos seus principais postulados. Seu objetivo é o de justificar o direito da sociedade em resistir aos arbítrios do monarca: sendo o governo um poder fiduciário conferido ao governante, havendo quebra da confiança pelo abuso na utilização das prerrogativas, o poder constituinte se legitima para estatuir um novo marco ao Estado.

A filosofia política de Locke é expressa principalmente na obra Segundo Tratado sobre o Governo Civil, na qual o autor apresenta os seus principais conceitos. John Locke vivenciou o declínio do absolutismo na Inglaterra e publicou a mencionada obra no mesmo ano da edição da Declaração de Direitos de 1689, documento normativo que estabelecia diversos impedimentos ao poder real. Neste sentido, a justificação do Estado em Locke se encontra na afirmação do Direito em detrimento ao divino poder monárquico do Ancien

\footnotetext{
${ }^{6}$ Nas palavras do autor, "entende-se que a obrigação dos súditos para com o soberano dura enquanto, e apenas enquanto, dura também o poder mediante o qual ele é capaz de protegê-los. Porque o direito que por natureza os homens têm de defender-se a si mesmos não pode ser abandonado através de pacto algum. A soberania é a alma do Estado e uma vez separada do corpo os membros deixam de receber dele seu movimento. O fim da obediência é a proteção, e seja onde for que um homem a veja, quer em sua própria espada quer na de um outro, a natureza manda a que a ela obedeça e se esforce por conservá-la” (HOBBES, 1997, p. 178).
} vol.09, no. 04, Rio de Janeiro, 2016.pp. 1865-1892 
Régime. Como pensador da política, valeu-se da obra de Thomas Hobbes e a utilizou como contraponto em suas principais formulações, opondo-se veementemente a toda forma de poder absoluto, contrária em demasia à liberdade dos cidadãos.

\section{O contraponto com Thomas Hobbes e a carência do estado de natureza}

A teoria política de John Locke é quase inteiramente centrada na questão da liberdade. Como jusnaturalista e contratualista, suas premissas partem da análise de um estado anterior ao momento de constituição da sociedade, realizada por meio de um pacto entre os cidadãos. Todavia, é necessário ter cautela ao analisar determinados conceitos, uma vez que o autor superou seus próprios escritos da juventude ao incorporar o racionalismo de René Descartes ao longo de sua trajetória acadêmica. De sorte que, segundo Abbagnano (2000, p. 177), em Ensaios sobre o direito natural, Locke ainda possuía certa influência teológica ao identificar o direito natural com o direito divino; todavia, mesmo nos primórdios de sua teoria filosófica, o pensador guardava uma característica essencial que o acompanhou pelos escritos do período da maturidade: o preceito de que os homens, por meio de um contrato consentido, teriam a faculdade de escolher o seu próprio governante. Já nos escritos da maturidade, sobretudo no texto Dois Tratados, o direito natural de Locke adquire autonomia racional. Em outras palavras, as leis naturais podem ser conhecidas por todos os indivíduos racionais.

A teoria política apresentada por Locke em Dois Tratados sobre o Governo Civil tem como escopo refutar as teses de Robert Filmer e seu livro Patriarca ou a potência dos Reis, na qual o autor defende a legitimidade da soberania real adquirida pela via do direito hereditário do próprio Adão, primeira criatura de Deus que é a fonte de todo o poder, a quem a divindade atribuiu toda a autoridade sobre o mundo. Por outro lado, o autor também rejeita a tese de Thomas Hobbes que prescrevia a soberania absoluta, concentrada nas mãos de um soberano, como meio para se encontrar a ordem e a paz social. Segundo Guido Fasso, o texto de Locke foi escrito em um momento em que a Inglaterra promovia amplo debate entre o absolutismo e o liberalismo político. O mote de John Locke é estatuir um Estado fundado na supremacia da legalidade, além de se preocupar com a manutenção da função judiciária ${ }^{7}$ na sociedade para que as querelas entre os cidadãos sejam resolvidas por autoridades competentes e imparciais (FASSO, 2012, p. 164). A lei fundada no Legislativo, deste modo, opõe-se a Filmer e Hobbes, pelo locus da soberania e não concentração do poder em vias hereditárias. Segundo esta visão lockeana, qualquer rei não estaria legítimo a invocar seu poder tendo por base o direito hereditário, nem tampouco seria

\footnotetext{
${ }^{7}$ Oportuno lembrar que, como será tratado adiante, a teoria política de John Locke não centrava sua discussão na separação das funções como a de Montesquieu. Por esta razão, Locke não viu a função judiciária como algo autônomo no Estado, assim como se verifica na atualidade. $\mathrm{O}$ enfoque do autor está na concepção de um estado cujo escopo é a legalidade. O pensador não se preocupa com formas de governo nem tampouco com a estrutura estatal, e sim com a esfera pública fundada na ordem da legislação para que fosse possível julgar as querelas entre os particulares.
} 
possível a uma comunidade constituir um soberano absoluto ${ }^{8}$. Para tanto, é necessário analisar o estado natural a que encontram os homens e compreender a necessidade de sua passagem para a vida em sociedade.

O pórtico de Dois Tratadosé a discussão acerca do estado de natureza. Sua concepção é profundamente distinta da teoria defendida por Thomas Hobbes, para a qual, conforme tratado anteriormente, os homens em seu estado natural viviam em guerra pelo caráter da ampla licenciosidade perpetrada pela liberdade de cada homem, o que gerava necessariamente inúmeros problemas. Sendo livres e desimpedidos para com todos os demais e caracterizados por seu egoísmo exacerbado, os seres humanos supostamente agiriam visando a satisfação de seus próprios desejos, entrando em conflito com os demais homens em igual condição. Assim, todos estariam submetidos a uma fórmula simples cujo resultado conduziria a um estado de guerra: os bens são escassos e os anseios sobrelevados. John Locke, por sua vez, distancia-se em demasia desta concepção hobbesiana. Para Locke, o estado de natureza se caracteriza por ser um estado de "perfeita liberdade", na qual os homens são livres para "regular suas ações e dispor de suas posses e pessoas do modo como julgarem acertado, dentro dos limites da lei da natureza". Ao mesmo tempo, é um estado de igualdade, "sendo recíproco todo o poder e jurisdição, não tendo ninguém mais que outro qualquer" (LOCKE, 1973, p. 41).

A par destes pressupostos, Locke descarta a hipótese deste estado de liberdade ser também um estado de licenciosidade, na qual a fruição de direitos individuais pudesse ultrapassar limites razoáveis de tolerância e ferir prerrogativas alheias. Dentre os direitos naturais, o autor elenca os direitos de propriedade - vida, liberdade, saúde, e propriedade - como de observância e preservação obrigatórias ${ }^{9}$. A este respeito, Nicola Abbagnano (2000, p. 178) comenta que a lei natureza é a única válida no estágio pré-contratual da vida dos homens, de modo que a liberdade consiste em não se submeter ao arbítrio de outrem e respeitar aos demais, o que exclui o conceito de liberdade como agir segundo suas próprias conveniências. A partir desta afirmação é possível constatar que, embora o conteúdo dos direitos naturais que mereçam salvaguarda vai além da propriedade privada dos indivíduos, a filosofia política de John Locke foi apropriada de modo simplório ao ser taxada simplesmente como liberal clássica, cujo escopo exclusivo seria a defesa da "propriedade".

Ao impedir que os próprios direitos sejam violados, cada pessoa é detentora da prerrogativa de agir em sua defesa. O castigo é consectário àquele que transgrediu um direito natural, legitimando o ofendido em sua prática mas na exata proporção da ofensa sofrida (algo próximo à Lei de Talião). Não se admite que a cólera

\footnotetext{
${ }^{8}$ Simone Goyard-Fabre (1986, p. 163) lembra que John Locke, além de possuir pensamento oposto ao absolutismo que pode conduzir a uma tirania, possuía ainda uma réaction affective com o tema, no seguinte sentido: "le problème de la tyrannie est de ceux qui obsèdent Locke depuis longtemps: lês conversations avec Shaftesbury, l'amitié avec Tyrrel, le désarroi du philosophe après l'exécution d'Algernon Sidney suffiraient à expliquer le corroux qui le dresse contre ce regime frelaté où rode une odeur de mort. Il nous est déjà apparu que, dans le climat enfiévré dês anées de la Restauration, Locke ne pouvait accepter l'idée d'um 'pouvoir absoluet arbitraire”
} vol.09, nº. 04, Rio de Janeiro, 2016.pp. 1865-1892 
consigne poder arbitrário ao ofendido, de modo a retroceder o estado natural a um modelo pautado na pura vingança. Assim, são duas as atitudes possíveis apresentadas por Locke para a realidade de um direito transgredido: revidar a ofensa, inclusive com a morte do ofensor caso isto seja necessário, ou exigir reparação pelo dano causado. A relação entre a responsabilidade civil e penal do ofensor pelo dano causado e a legitimidade que o ofendido detém para revidar o ato ou exigir sua reparação conduz ao que Locke denomina estado de guerra lembrando que esta é a realidade corriqueira do próprio estado de natureza em Hobbes: quando há situações na qual os homens não possuem uma autoridade para julgar e decidir os direitos.

Deste modo, o estado natural para Locke pode ser descrito e resumido pela ausência de uma autoridade superior que possa julgar as querelas naturalmente surgidas na vida em comunidade. Se em Hobbes o abuso da liberdade constitui o estado de guerra, em Locke se atinge esta situação quando é dado a cada um julgar segundo a conveniência de sua própria lei e juízo e executar o castigo que julgar apropriado de acordo com a dosimetria que achar conveniente. Em outras palavras, o estado de natureza dos homens possui três carências irreprimíveis: carece de uma lei estabelecida, fixa e conhecida, recebida e aceita mediante o consentimento comum; de um juiz conhecido e imparcial, com autoridade para solucionar todas as diferenças de acordo com a lei estabelecida, evitando-se atitudes passionais; e ainda não possui, freqüentemente, um poder que valide a sentença fundada na legalidade e a execute, conduzindo a uma condição de maior segurança pessoal e jurídica (LOCKE, 1973, p. 73 e $88)$.

Neste sentido, Guido Fasso comenta que a lei da natureza na concepção lockeana não precisaria ser positivada pois poderia ser conhecível por todos através da razão; mas que o estado de natureza carecia de uma lei fixa, conhecida por todos, admitida por consenso comum, de um sistema julgador estável e imparcial e da autoridade do Estado para dar força às sentenças. Em seus termos:

La legge di natura sai evidente ed intelligibile a tutte le creature razionali, non tutti sono disposti a 'riconoscerla come legge vincolante nella sua applicazione ai loro casi particolari'; siché si sente la mancanza nello stato di natura governato da essa, di una legge stabilita, fissa, conosciuta (establish'd, settled, known law), accolta ed ammessa per consenso comune come mistura (standard) del diritto e del torto; si sente il bisogno di um giudice conosciuto e imparziale che abbia l'autorità di dirimere tutte le controversie in conformità della legge stabilita, perché della legge di natura ciascuno è egli stesso giudice ed esecutore, e gli uomini sono parziali nei propri riguardi e di lasciano trascinare dalla passione e dalla vendetta; infine nello stato di natura si sente la mancanza di un'autorità che dia forza alle sentenze giuste e le eseguisca (FASSO, 2012, p. 160-161).

Assim, Locke quer demonstrar que o estado de licenciosidade pode conduzir a deflagração de um estado de guerra assinalado pela inimizade e destruição, caracterizado pela utilização da violência como artefato de uma

\footnotetext{
${ }^{9}$ Segundo Locke: "o estado de natureza tem uma lei de natureza para governá-lo, que a todos obriga; e a razão, que é essa lei, ensina a todos os homens que tão só a consultem, sendo todos iguais e independentes, que nenhum deles deve prejudicar a outrem na vida, na saúde, na liberdade e nas posses" (LOCKE, 1973, p. 42).
} 
justiça de reciprocidade, nos moldes da lei de Talião ${ }^{10}$. Evitar este complexo de atitudes vingativas é a razão da passagem do estado de natureza para a vida em sociedade:

Evitar este estado de guerra - no qual não há apelo senão aos céus, e para o qual pode conduzir a menor das diferenças, se não houver juiz para decidir entre os litigantes - é a grande razão para que os homens se reúnam em sociedade deixando o estado de natureza; onde há esta autoridade, poder sobre a Terra, do qual é possível obter amparo mediante apelo, exclui-se a continuidade do estado de guerra, decidindo-se a controvérsia por aquele poder (LOCKE, 1973, p. 48).

Desta maneira, observa-se que, a despeito de o estado de natureza se constituir como uma condição de liberdade e igualdade, existem razões que conduzem os indivíduos a desejarem limitar estes direitos naturais em busca de uma vida em sociedade. Com efeito, Locke reconhece que a existência de qualquer sociedade política é impossibilitada sem que se preserve a propriedade (lato sensu) e, para isto, castiguem-se as condutas que violem o dispositivo legal. Assim, cabe aos homens outorgar duas faculdades que constituem o arcabouço de seus direitos naturais, mas que constituem e possibilitam a vida em sociedade: o poder de agir propiciando a auto-preservação, que será substituído pelas leis comuns, elaboradas pela sociedade; e o poder de castigar os crimes, que será função do pode executivo da sociedade.

Ao se excluir o julgamento privado, é a comunidade que será chamada para realizar tal função entre qualquer membro e sobre qualquer assunto jurídico por meio de autoridades constituídas (LOCKE, 1973, p. 73). Em outros termos, os dois poderes supremos retirados do arbítrio dos cidadãos e postos a serviço da sociedade são o de julgar as atitudes que infrinjam a norma estabelecida pela maioria (poder na elaboração legislativa) e o de punir aqueles que causaram dano (poder de guerra e paz) ${ }^{11}$.

\section{A constituição do estado social}

A passagem do estado de natureza para a vida em comunidade se justifica em prol da preservação dos direitos naturais. A finalidade da união dos homens em sociedades políticas e conseqüente submissão a um governo é a conservação da propriedade - vida, saúde, liberdade e propriedade. Em suma, o estado social é caracterizado pela existência da união das pessoas em uma comunidade que conjuga a mesma lei e judicatura. Assim, o conceito de poder em Locke não se confunde com força, mas com um complexo de direitos assumidos em sociedade.

\footnotetext{
${ }^{10}$ Segundo Locke (1973, p. 64), "pode-se destruir um homem que promove a guerra contra nós ou manifestou inimizade a nossa existência, pela mesma razão por que se pode matar a um lobo ou a um leão; porque tais homens não estão submetidos à lei comum da razão e não têm outra regra que não a da força e da violência, e, portanto, podem ser tratados como animais de presas, criaturas perigosas e nocivas que seguramente nos destruirão se cairmos em seu poder".

11 "E assim, tendo sido excluído o juízo particular de cada membro individual, a comunidade passa a ser o árbitro mediante regras fixas estabelecidas, imparciais e idênticas, para todas as partes, e, por meio dos homens que derivam sua autoridade da comunidade para a execução dessas regras, decide todas as diferenças que porventura ocorram entre quaisquer membros dessa sociedade acerca de qualquer questão de direito; e pune com penalidades impostas em lei os delitos que qualquer membro tenha cometido contra a vol.09, no. 04, Rio de Janeiro, 2016.pp. 1865-1892 1878
} 
Segundo Locke, dadas as deficiências mencionadas no estado de natureza, somente a vida em sociedade torna esta salvaguarda realizável através dos aparatos criados a partir do consentimento, e não submissão. $\mathrm{O}$ principal deles é a lei, sendo o Legislativo algo de grande estima para o filósofo inglês, a ponto de não apenas conferir-lhe a supremacia dentre as demais funções como também denominá-lo "sagrado e inalterável nas mãos em que a comunidade o tenha antes depositado" (LOCKE, 2005, 503). Dadas as razões que levaram Locke a escreve Dois Tratados, quais sejam a manifesta oposição ao absolutismo do poder executivo, tal apreço pelo Legislativo é compreensível e razoável.

Pensando um Estado baseado na supremacia da lei, Locke relacionava as limitações da liberdade pessoal aos limites da legislação válida. Seu intento era vedar o arbítrio, isto é, impedir que a liberdade ficasse sujeita "à vontade inconstante, incerta e arbitrária de qualquer homem" (LOCKE, 1973, p. 49). Deste modo, o autor se afasta de pensadores como Maquiavel e Hobbes, para os quais a possibilidade de organização do Estado se concentra no príncipe ou no Leviatã, não restando papel para o Legislativo.

O consentimento é uma característica fundamental no Estado idealizado por Locke. É ele que constantemente se encontra em uma situação de insegurança no estado de natureza, por meio dele que se realiza o contrato social para a formação da sociedade e somente por ele se confere a autoridade ao Legislativo para criar as leis da comunidade política. Além de um ato de liberdade é a sua própria garantia, ensina Nicola Abbagnano. Ainda segundo este autor, a natureza da sociedade fundada na legislação é exatamente a aquiescência. $O$ consenso como um ato de liberdade de escolha visa garantir e manter a liberdade, de modo que não pode ser usado para legitimar a sujeição de alguém à "inconstante, incerta e arbitrária vontade outro homem” (ABBAGNANO, 2000, p. 179). Assim, quando os homens assentem para a formação da sociedade política, assumem também a regra de que a vontade da maioria prevalecerá sobre os interesses particulares. Neste sentido, Locke lembra que a contrariedade de interesses é dinâmica corriqueira em qualquer reunião de homens em comunidade, e que o grupo dos vencidos não pode romper o contrato por este motivo pois nenhuma constituição seria possível sob tais condições, salvo se as leis editadas ferirem os direitos naturais.

Segundo John Rawls (2012, p. 137), Locke reforça em sua obra um consentimento por formação. Isto ocorre na hipótese de constituição de um novo corpo político a partir de um pacto social. Sua exata antítese é o consentimento por adesão, na qual os indivíduos são compelidos a adentrarem em uma esfera política já constituída. Desta maneira, o contrato constituinte da sociedade política se fundará no consentimento e ensejará o nascimento do Estado com funções distintas, sendo a principal delas a legislativa. Locke apresenta três possíveis formas de Estado, tendo como critério distintivo o modo de aplicação do poder. Se o poder reunido é colocado em um corpo de funcionários eleitos e responsáveis pela edição de leis comuns, esta será uma democracia. Se o

sociedade. (LOCKE, 1973, p. 73)". vol.09, no. 04, Rio de Janeiro, 2016. pp. 1865-1892 
poder Legislativo for conferido a um grupo de pessoas e, posteriormente, a seus herdeiros, falar-se-á de uma oligarquia. Por sua vez, se a produção legislativa estiver nas mãos de uma pessoa, haverá uma monarquia que possui duas espécies, hereditária ou eletiva (LOCKE, 1973, p.91).

A sociedade civil arquitetada por ele não conhece poderes absolutos. Simone Goyard-Fabre (1986, p. 164) em seu em seu livro John Locke et la raison raisonnable comenta que o tirano, como um usurpador, distorce e desnatura a autoridade do Estado legal, assim como sua força destrói o direito; o tirano encarna a negação da essência política que se almeja com o estado social, ofendendo la raison, le droit et la nature ${ }^{12}$. O intento da vida em sociedade está em remediar o mal do estado de natureza, que consiste em cada homem ser juiz em causa própria. Com efeito, remedia-se tal situação com leis e magistrados que conhecerão das controvérsias e as resolverão. Em hipótese contrária, o soberano no estado absoluto, qualquer que seja a sua forma, concentra todo o poder de legislar e executar os comandos em sua própria vontade, não se observando a possibilidade de uma decisão judiciária imparcial.

Em se tratando das funções do Estado, é conhecida a divisão de Locke em poder legislativo, executivo e federativo. Para o autor, definida entre os homens a necessidade de se pactuar pela constituição da sociedade civil, a primeira lei positiva deste estado será a que comporá o poder Legislativo, classificado como supremo, sagrado e inalterável. É ele que estabelecerá como a "força da comunidade" será utilizada da melhor forma possível visando a sua preservação (LOCKE, 1973, p. 92-95). Locke destina quatro encargos fundamentais aos legisladores e governantes, independente da forma adotada pelo Estado. Primeiro, a sociedade deve ser governada mediante leis promulgadas gerais, não estabelecendo distinções entre os cidadãos. Segundo, toda a legislação deve visar o bem comum do povo. Terceiro, o aumento de impostos sobre a propriedade privada não pode ser feito de modo arbitrário, mas deve passar pelo corpo Legislativo constituído. E, por fim, a função de elaborar as leis não pode ser transferida sem o consentimento dos cidadãos.

Ainda que considerado o poder supremo e sagrado dentre todas as funções do Estado, Locke deixou muito claro que o poder legiferante não é absoluto e nem tampouco arbitrário, pois está impedido de exceder o poder que os cidadãos tinham ainda em estado de natureza. O poder Legislativo sob qualquer enfoque, "restringese ao bem público da sociedade. É poder que não tem outro objetivo senão o da preservação e, portanto, não poderá ter nunca o poder de destruir, escravizar ou propositalmente empobrecer os súditos” (LOCKE, 1973, p. 93). Para Locke, a legitimidade do processo legislativo é algo de suma importância, pois resume a motivação dos homens a autolimitarem sua liberdade para adentrar na sociedade política e representa o consentimento de todos para a preservação da ordem neste Estado. Além disso, não podem os legisladores arrogarem para si a governança

\footnotetext{
12 "Le tyran est donc celui qui, comme l'usurpateur, provoque uma distorsion et une dénaturation de l'autorité civile. Il peut, à la différence de l'usurpateur, avoir été institué de manierè legitime. Mais, dans l'exercice Du pouvoir, Il méconnait, comme vol.09, nº. 04, Rio de Janeiro, 2016.pp. 1865-1892 1880
} 
por meio de decretos extemporâneos, nem tampouco limitar a propriedade de uma pessoa sem seu consentimento, mas deve visar somente o bem do povo. Conferir ao mesmo grupo de homens o poder de criar e aplicar a lei gera um abuso de prerrogativas em detrimento da lei natural ínsita a cada cidadão.

As outras duas funções que compõem o governo de Locke são a executiva e a federativa. A primeira aplica a lei editada e publicada no âmbito interno da comunidade política, enquanto o poder federativo cumpre a função de promover alianças e transações com as pessoas e com as sociedades políticas internacionais. Uma diferença importante entre Locke e Hobbes está na possibilidade de dissolução do governo. Enquanto o pacto hobbesiano era perpétuo, para Locke a função do governo está adstrita à preservação da liberdade e da propriedade. Caso ele não seja capaz de assegurar os direitos naturais dos cidadãos, estes possuem o poder de salvaguarda de si, podendo retirar o seu consentimento à formação do Estado.

Isto se justifica, como apontado, que o intento de Locke com o equacionamento da sociedade política está na defesa dos direitos naturais, sobretudo a liberdade e a vida. $\mathrm{O}$ abandono consentido do estado de natureza permitiria o desenvolvimento de um governo fundado na observância da lei civil e salvaguarda dos preceitos naturais. Locke deslegitima o império da vontade soberana e estatui a ordem pública no império da lei e do direito. Este seria o único meio possível para os cidadãos terem seus direitos preservados e obterem a justiça. Esvaziando as possibilidades de um estado de guerra pelo mau uso da liberdade, haveria instituições com diferentes funções para guarnecer o cidadão, proporcionando o desenvolvimento da própria sociedade e a possibilidade do desenvolvimento de uma vida conveniente para as pessoas.

\section{O NEOCONTRATUALISMO DE JOHN RAWLS}

John Rawls, professor da Universidade de Harvard, é considerado um dos principais filósofos do Direito de todo o século XX. Sua densa obra Uma Teoria da Justiça se constitui em importante marco em razão de ter retomado o tema da justiça nas instituições. $\mathrm{O}$ intuito aqui será o de apresentar os conceitos fundamentais desenvolvidos neste livro, como posição original e véu da ignorância. Além disso, pretende-se trabalhar propriamente os dois princípios da justiça, elementos propulsores fundamentais para a busca da justiça em um governo democrático.

É importante notar que o intento de John Rawls é estabelecer um conceito de justiça para as instituições sociais. Abre-se, portanto, um flanco novo e diferente na teoria contratual desenvolvida. Esta diferença é compreensível em virtude dos momentos históricos serem absolutamente distintos: separados por mais de dois séculos, enquanto os autores precedentes buscavam meios para justificar a existência do próprio Estado moderno,

l'usurpateur, le droit, la justice et la raison. Chez lui, la force - ou la ruse - supplante le droit; l'intérêt prive tient place d'intérêt public; l' outrance tient lieu de règle; la passion chasse toute raisson" (GOYARD-FABRE, 1986, p. 164). 
Rawls dispõe das instituições estatais estabelecidas mas pretende repensá-las a partir do ideal de justiça.

\begin{abstract}
Meu objetivo é apresentar uma concepção de justiça que generalize e eleve a um nível mais alto de abstração a conhecida teoria do contrato social conforme encontrada em, digamos, Locke, Rousseau e Kant. Para isso, não devemos achar que o contrato original tem a finalidade de inaugurar a determinada sociedade ou de estabelecer uma forma específica de governo. Pelo contrário, a idéia norteadora é que os princípios de justiça para a estrutura básica da sociedade constituem o objeto do acordo original. São eles os princípios que pessoas livres e racionais, interessadas em promover seus próprios interesses, aceitariam em uma situação de igualdade como definidores das condições fundamentais de sua associação (RAWLS, 2008, p. 13-14).
\end{abstract}

A intenção que subjaz tanto aos autores contratuais como a própria idéia rawlsiana é estabelecer um modelo pelo qual as pessoas estabelecerão as suas vidas, o que em última análise revela a tentativa de estabelecer algum parâmetro de controle para a complexidade do comportamento social. De fato, esta constitui uma das temáticas primevas e mais presentes tanto na filosofia política como no Direito. Assim, o objetivo da justiça como equidade de John Rawls, nos termos de Wayne Morrison (2006, p. 469-470), é "oferecer uma teoria razoável que contenha um conjunto básico de princípios com os quais possamos obter o consenso no debate sobre a justiça".

A teoria de John Rawls, portanto, reinaugura o arquétipo do contrato social ${ }^{13}$ exatamente por pensar em uma nova sociedade que seria fundada por determinados princípios de ação: o autor não pretende apontar qual a melhor forma de Estado ou governo, como fizeram Platão ou Aristóteles, por exemplo, mas identificar quais seriam os princípios basilares da justiça para uma sociedade e identificar as suas instituições a tal base comparativa. Neste sentido, Rawls não necessariamente coaduna as teses substanciais dos contratualistas, como Hobbes e Locke (cujo pensamento foi trabalhado), Rousseau ou Kant, mas se vale da essência teórica do conjunto de proposições para lançar o seu olhar sobre a sociedade.

Feita tal consideração, Rawls desde o limiar de seu texto deixa muito evidente a centralidade do conceito de justiça para as instituições sociais. Segundo ele, "a justiça é a virtude primeira das instituições sociais, assim como a verdade o é dos sistemas de pensamento ${ }^{14 ”}$. A fundamentação de uma teoria da justiça no bojo da tradição democrática é o seu principal intento de modo a fornecer uma "alternativa sistemática razoável ao utilitarismo ${ }^{15 "}$ (RAWLS, 2008, p. XXXVI). Todavia, a busca por um critério que padronize o conceito de justiça não é novo e

\footnotetext{
${ }^{13}$ Rawls (2008, p. 19-20) aloca a sua teoria da justiça como equidade como "um exemplo do que chamo de teoria contratualista". Ainda em suas palavras, "o mérito da terminologia contratualista é expressar a idéia de que os princípios da justiça podem ser concebidos como princípios que seriam escolhidos por pessoas racionais e que, assim, é possível explicar e justificar as concepções de justiça”. Ainda acerca de sua opção pela idéia da teoria contratual, ele aduz que "a palavra 'contrato' indica essa pluralidade, bem como a condição de que a divisão apropriada das vantagens esteja de acordo com princípios aceitáveis por todas as partes”.

${ }^{14}$ Ainda segundo Rawls, "por mais elegante e econômica que seja, deve-se rejeitar ou retificar a teoria que não seja verdadeira; da mesma maneira que as leis e as instituições, por mais eficientes e bem organizadas que sejam, devem ser reformuladas ou abolidas se forem injustas" (RAWLS, 2008, p. 04).

${ }^{15}$ Esta consideração foi feita no prefácio à segunda edição da obra escrita por Rawls no ano de 1990. Ele alega que a fragilidade "da doutrina utilitarista para servir de base às instituições da democracia constitucional” constitui o seu grande propósito para buscar uma alternativa às teses utilitárias. "Não acredito, acima de tudo", assevera Rawls, "que o utilitarismo consiga oferecer uma teoria satisfatória dos direitos e das liberdades fundamentais dos cidadãos como pessoas livres e iguais, requisito da mais alta importância para a teoria das instituições democráticas"
} 
Rawls certamente não é o primeiro e nem será o último autor a pensar em uma teoria com tal desiderato.

Podendo ser analisada sobre inúmeros prismas e vieses distintos, a abordagem de Rawls se desenvolve com o intuito de fornecer parâmetros principiológicos na determinação dos direitos e deveres que constituem a base da própria cidadania democrática e condição sine qua non do Estado de Direito ${ }^{16}$. O autor também deixa claro tal intento ao dizer que "o objeto principal da justiça é a estrutura básica da sociedade, ou, mais precisamente, o modo como as principais instituições sociais distribuem os direitos e os deveres fundamentais e determinam a divisão das vantagens decorrentes da cooperação social” (RAWLS, 2008, p. 08).

\section{Traços gerais para uma teoria da justiça}

A teoria da justiça de John Rawls é identificada como uma tentativa de encontrar um parâmetro moral básico da sociedade para que se possa, a partir de então, quando necessário, avaliar políticas fundamentais sob o prisma das instituições sociais de determinado país de modo a se fazer a justiça para todos. Consoante a análise de Werle (2015, p. 263), a teoria rawlsiana é um padrão voltado para as instituições, em primeiro plano, e somente de modo secundário para os indivíduos à medida que "estes vivem e levem adiante seus planos de vida sob as regras públicas estabelecidas por aquelas instituições". O próprio Rawls esclarece em seu texto que não pretende estabelecer uma teoria fundadora de uma sociedade hipotética, mas encontrar os princípios básicos sobre os quais a sociedade seria erigida e a concepção de justiça seria localizada. Em outras palavras, Rawls busca identificar um padrão pelo qual a sociedade pudesse se reconfigurar. Aqui está presente a essência do contrato social. Em suma, Rawls é um contratualista não por buscar um fundamento para o Estado, mas por decantar as instituições estatais existentes em princípios de modo a se obter justiça a todos.

Sua teoria deve ser aplicada em duas circunstâncias. A primeira circunstância são questões de justiça distributiva decorrentes da escassez moderada dos recursos - isto é, a característica mais notória de qualquer teoria moderna que reconhece que os recursos são exauríveis e as necessidades podem ser quase infindas -, e visam determinar as regras fundamentais da distribuição dos benefícios e encargos que são originados pela cooperação da sociedade. Uma vez que qualquer teoria de justiça precisa atacar o problema das profundas desigualdades sociais, Rawls não tem interesse em deixar esta importante questão no livre jogo dos mercados. Para tanto, estabelece os princípios básicos de justiça que se aplicarão à estrutura da sociedade.

A segunda circunstância se relaciona às questões de tolerância, isto é, são necessários princípios de justiça para especificar direito e deveres dos cidadãos. Qualquer sociedade somente pode vicejar a partir da mínima coesão entre direitos e obrigações: a despeito de uma população comungar de uma mesma sociedade, entre si

\footnotetext{
${ }^{16}$ A este respeito, Denílson Luis Werle comenta que "a teoria da justiça de Rawls pretende fornecer um conjunto de princípios capaz de evitar a arbitrariedade moral na determinação dos direitos e deveres dos cidadãos e fornecer um ponto de vista comum a partir do qual reivindicações conflitantes dos cidadãos possam ser julgadas (WERLE, 2015, p. 263)
} 
reina a total disparidade de planos de vida, crenças, culturas, religiões, modos de pensar a política e a moral, entre outros elementos sociais. Deste modo, é preciso oferecer algum tipo de organização a todos estes contrastes. (WERLE, 2015, p. 264).

Para encarar este desafio, Rawls se identifica com uma das principais idéias da moralidade para os autores liberais, qual seja, a sobreposição da justiça em relação ao bem comum, concepção contrária a dos comunitaristas. Esta é a principal característica da teoria da justiça como equidade: a imposição de alguns critérios de justiça na moldagem da estrutura básica da sociedade. Desta forma, "impõe-se certos limites iniciais ao que é bom e quais formas de caráter são moralmente dignas, e também aos tipos de pessoas que os seres humanos devem ser" (RAWLS, 2008, p. 38-39). O objetivo destas limitações, comuns a todas as teorias da justiça, visam à satisfação dos princípios fundamentais nas circunstâncias vigentes.

A tese da justiça preceder o bem, como um reflexo do modus operandi argumentativo das teorias kantianas, conduz a dois meios de compreensão. O primeiro é a defesa normativa da inviolabilidade da pessoa, ou seja, a autonomia pessoal deve ser preservada em detrimento a todas as considerações coletivas de bem-estar e de bem comum ${ }^{17}$. A segunda concepção decorrente é o da neutralidade de justificação do Estado em face de concepções particulares do bem. Aqui se fazem necessários os princípios fundamentais que sirvam como bastião em uma sociedade plural e heterogênea da qual emergem inúmeras concepções de vida. $\mathrm{O}$ importante na adoção dos princípios é que deslegitima qualquer concepção particular de bem alçada a guiar a sociedade, pois tal atitude frustraria a autonomia e a liberdade dos indivíduos ${ }^{18}$.

É necessário ter em vista que a justiça como equidade é uma tese de John Rawls que se propõe a pensar um sistema de igualdade de cooperação social, na qual se encontram pessoas livres e iguais entre si. A questão fundamental está em se estabelecer o que é justo e o que é injusto para aquela determinada sociedade. No bojo desta discussão, Rawls procura retirar toda espécie de particularismo ao expor uma estrutura pública e objetiva: fugindo da tentação de dizer o que é a justiça para a sociedade, ele consigna dois princípios como alicerce da busca

\footnotetext{
${ }^{17}$ Segundo Rawls: "cada pessoa possui uma inviolabilidade fundada na justiça que nem o bem-estar de toda a sociedade pode desconsiderar. Por isso, a justiça nega que a perda da liberdade de alguns se justifique por um bem maior desfrutado por outros. Não permite que os sacrifíios impostos a poucos sejam contrabalançados pelo número maior de vantagens de que desfrutam muitos. Por conseguinte, na sociedade justa as liberdades da cidadania igual são consideradas irrevogáveis; os direitos garantidos pela justiça não estão sujeitos a negociações políticas nem ao cálculo de interesses sociais" (RAWLS, 2008, p. 04).

${ }^{18}$ Valendo-se de Werle, a formulação da tese que prioriza o justo sobre o bem determina e exige que "os princípios de justiça sejam justificados por meio de razões que todos os cidadãos, imersos em eticidades diferentes, poderiam aceitar (ou pelo menos por razões que ninguém poderia razoavelmente rejeitar), independentemente do recurso à coerção". Tal assertiva é ponto comum entre os autores do liberalismo por estruturar a noção de autonomia em detrimento à imposição pelo ente público de concepções de vida que frustrem a escolha pessoal aceitável por cada indivíduo. Nas palavras de Rawls (2008, p. 13-15): "a idéia norteadora é que os princípios de justiça para a estrutura básica da sociedade constituem o objeto do acordo original. São eles os princípios que pessoas livres e racionais, interessadas em promover seus próprios interesses, aceitariam em uma situação inicial de igualdade como definidores das condições fundamentais de sua associação. Esses princípios devem reger todos os acordos subseqüentes; especificam os tipos de cooperação social que se podem realizar e as formas de governo que se podem instituir [...] Devemos imaginar que aqueles que entram em cooperação social escolhem juntos, em um único ato conjunto, os princípios que devem vol.09, n. 04, Rio de Janeiro, 2016. pp. 1865-1892 1884
} 
pelo justo. Antes de abordar os princípios em si, é necessário justificá-los. A validação normativa de sua tese moral da justiça como equidade encontra vazão em dois pontos de sustentação. $O$ primeiro deles é a posição original sob o véu da ignorância e o segundo o equilíbrio reflexivo.

\section{Véu da ignorância e equilíbrio reflexivo}

A posição original é considerada um preceito teórico ainda mais abstrato do que a tese dos contratualistas em geral, e comunga do fato de ser uma situação puramente hipotética. Segundo Rawls, esta posição corresponde ao estado de natureza das teorias contratuais tradicionais e dispõe das seguintes características: a ignorância é a condição em que ninguém conheceria seu lugar na sociedade, sua classe ou seu status social, nem tampouco a sorte na distribuição dos recursos e das habilidades naturais, sua inteligência, força e coisas do gênero (RAWLS, 2008, p. 13-15). Estas assertivas constituem para John Rawls o chamado véu da ignorância, ou seja, o estado em que não haveria qualquer conhecimento prévio de posição social na escolha dos princípios de justiça.

O que Rawls está dizendo o seguinte: para se eleger os princípios sociais de um modo justiça, é necessário estabelecer um meio para evitar que os indivíduos não possam, de maneira alguma, valer-se de sua condição privilegiada para minimamente conseguir prever onde estariam na sociedade. A escolha, ocorrida nesta situação hipotética sob o véu da ignorância, garantiria em tese que não haja nenhuma sorte de favorecimentos na eleição dos princípios, escolhas baseadas em informações secretas ou ainda privilégios a classes que eventualmente possuam maior preponderância na arquitetura social. Isto ficará mais claro ao final do próximo ponto, quando se abordar substancialmente os dois princípios de justiça.

A conseqüência da escolha realizada sob este véu da ignorância é o que permite a Rawls intitular a sua teoria de justiça como equidade, ou seja, há um apelo pela isonomia na constituição dos princípios basilares que inspiram a reconstrução social. Segundo Rawls, o véu garante que não haja favorecimentos na escolha dos princípios, seja pelo acaso natural seja por circunstâncias sociais, uma vez que "todos estão em situação semelhante e ninguém pode propor princípios que favoreçam sua própria situação". Por conseguinte, "os princípios de justiça são resultantes de um acordo ou pacto justo" ${ }^{19}$.

O véu da ignorância é um ponto elementar na teoria como equidade, pois é o que garante a isonomia dos cidadãos, velando para que não prevaleçam peculiaridades que pudessem ensejar em benefício ou malefício de uma classe de cidadãos, como questões de gênero, posição geográfica, doutrinas morais, políticas ou religiosas,

atribuir os direitos e os deveres fundamentais e determinar a divisão dos benefícios sociais”.

${ }^{19}$ E prossegue Rawls: "dadas as circunstâncias da posição original, a simetria das relações de todos para com todos os demais, essa situação inicial é equitativa entre os indivíduos tidos como pessoas morais, isto é, como seres racionais com objetivos próprios e capacitados, presumirei, para ter um senso de justiça. A posição original é, pode-se dizer, o status quo apropriado e, assim, os vol.09, nº. 04, Rio de Janeiro, 2016. pp. 1865-1892 1885 
entre tantos outros elementos específicos pelos quais se constituem pequenos grupos com identidades semelhantes ${ }^{20}$. A posição original, portanto, é este "artifício de representação" ou "procedimento de justificação" que conjuga os princípios de justiça - razão teórica - às formalidades da razão prática; mais do que isto, "ela formaliza o ponto de vista moral imparcial que possibilita a escolha de princípios para julgar as questões políticas fundamentais" (WERLE, 2015, p. 269).

O segundo ponto de sustentação de sua teoria de justiça como equidade é o equilíbrio reflexivo. Por meio dele se busca a harmonia entre os juízos morais particulares e os princípios de justiça. Nos termos de Silveira (2009, p. 147), o objetivo de Rawls é alçar a teoria da justiça equitativa como sendo o senso de justiça fundamental de modo que os princípios escolhidos na posição original sob o véu da ignorância correspondam aos juízos ponderados por toda a sociedade. Porém, esta concepção representa o ideal, e Rawls sabe que é preciso algum método que dialogue entre os princípios de justiça e os juízos ponderados particulares. A idéia elementar pode ser trabalhada pelas seguintes assertivas: primeiro, partir de juízos morais concordantes entre todas ou pelo menos a maioria das sociedades democráticas - como, por exemplo, a tolerância religiosa ou a liberdade de expressão e imprensa -, identificando sua coerência com os princípios de liberdade e de igualdade. Depois utilizar os princípios da justiça como niveladores de juízos morais em que haverá discordância, como os critérios para a distribuição de bens perante a sociedade. Por fim, tais juízos terem por base uma teoria moral e política, como, por exemplo, a que faz uma leitura da justiça a partir da equidade dos cidadãos entre $\mathrm{si}^{21}$. Assim, o método de equilíbrio reflexivo visa revisar crenças particulares em contraste a crenças invariáveis - ou seja, entre os princípios ponderados que, no caso de Rawls, são os princípios de justiça - de modo a obter a melhor forma de diálogo possível entre tais crenças, aproximando os princípios de justiça do cotidiano de julgamentos morais das pessoas.

Todo este procedimento de justificação da justiça não teria fundamento no caso de John Rawls não apresentar uma concepção substantiva do que ele compreende por justiça. No caso de sua teoria, isto concerne especificamente em apontar quais são especificamente os princípios de justiça. Deste modo, o itinerário intelectual de Rawls para a definição da teoria da justiça como equidade passa pela escolha dos princípios basilares

consensos fundamentais alcançados nela são equitativos" (RAWLS, 2008, p. 15).

${ }^{20}$ A este respeito, Werle (2015, p. 267) aduz que "a posição original assegura a imparcialidade e equidade na escolha dos princípios, de modo que sua justificação não dependa de razões éticas particulares, das características e circunstâncias particulares de uma eticidade particular. $\mathrm{O}$ véu da ignorância explicita as condições razoáveis que delimitam o espectro de razões e informações moralmente válidas, isto é, que podem fundamentar princípios de justiça numa sociedade marcada pelo pluralismo. Nesse sentido, para justificar a escolha dos princípios, as partes não podem contar com boas razões, seja a sua posição particular na sociedade, seja o fato de professarem uma doutrina religiosa, filosófica ou moral abrangente, ou uma concepção particular do bem. Também têm de ser excluídas informações sobre a raça e o grupo étnico, diferenças de gênero e os diversos talentos naturais.

${ }^{21}$ Silveira (2009, p. 148) apresenta uma conclusão elucidativa de que o método de equilíbrio reflexivo "é um processo de justificação de crenças, garantindo a identificação da objetividade dos juízos e princípios morais com base na coerência entre eles, sendo um teste para a validação do senso de justiça compartilhado, estabelecendo-se princípios morais de acordo com uma teoria moral e com as convicções morais refletidas, conformando, além disso, os juízos morais convergentes com base na coerência com os princípios da justiça como equidade". 
da concepção da justiça que devem regular todas as críticas e reformas subseqüentes das instituições existentes, ou seja, tais princípios constituem um ponto arquimediano em sua obra. A despeito de se aproximar do contratualismo, o autor não pretende lançar sua teoria na fundação do Estado, mas adaptar uma sociedade já existente. Em razão disto, após a escolha destes princípios que norteiam a concepção de justiça, a sociedade promulgará uma constituição e uma legislatura em consonância aos princípios acordados inicialmente na posição original de modo a paulatinamente transformar toda a sociedade como um reflexo de tais princípios. O objetivo é de que a sociedade se torne mais justa e igual.

\section{Os princípios de justiça}

John Rawls sustenta que as pessoas, na condição de posição original sob o véu da ignorância, dentre todas as hipóteses possíveis, provavelmente escolheriam os dois princípios seguintes. Em seus precisos termos:

Primeiro: cada pessoa deve ter um direito igual ao sistema mais extenso de iguais liberdades fundamentais que seja compatível com um sistema similar de liberdades para as outras pessoas.

Segundo: as desigualdades sociais e econômicas devem estar dispostas de tal modo que tanto (a) se possa razoavelmente esperar que se estabeleçam em benefício de todos como (b) estejam vinculadas a cargos e posições acessíveis a todos (RAWLS, 2008, p. 73).

Este é um ponto relativamente criticado de seu pensamento, por crer que todos desejariam exatamente estes mesmos princípios. É preciso, todavia, compreende-los. $\mathrm{O}$ autor aduz que os princípios são distintos entre si para se adequarem à sociedade que também o é: um sistema social define e garante as liberdades e o segundo especifica e estabelece as desigualdades econômicas e sociais ${ }^{22}$. O primeiro princípio é o que Wayne Morrison (2006, p. 471) qualifica de "precedência operacional", isto é, trata-se de uma forma de assegurar que a liberdade preceda todos os demais princípios em escala de importância. Não é por qualquer outra razão que John Rawls é um pensador liberal. Desta maneira, ele aponta algumas das espécies de liberdades e demais direitos que estariam incluídos no âmbito do primeiro princípio: liberdade política (direito ao voto e de exercer cargo público), liberdade de expressão e reunião, de consciência e de pensamento, liberdade individual ou integridade física das pessoas (proteção contra a opressão psicológica, agressão e mutilação), direito à propriedade pessoal e proteção contra prisão e detenção arbitrárias.

O autor não deixa dúvidas que, de fato, a defesa da liberdade se encontra em posição privilegiada sobre todos os demais princípios e direitos, em especial aos princípios de justiça distributiva. Acerca da prioridade da liberdade, John Rawls aponta que "a primazia da liberdade significa que a liberdade só pode ser limitada em nome da própria liberdade" (RAWLS, 2008, p. 302-303). Em outras palavras, Rawls está afirmando que não é legítima a limitação da liberdade de um grupo para melhorar as condições sociais de outro grupo, ainda que o conjunto dos 
desfavorecidos seja substancialmente maior ${ }^{23}$. Com isto o autor cumpre com a finalidade liberal ao não pensar em criar sistemas que privilegiem o bem comum em detrimento do individual (conforme tratado anteriormente).

Rawls, no entanto, admite dois vieses: o de que a liberdade de algumas pessoas seja praticamente igual entre si, o que não justifica nenhuma atitude positiva, ou ainda que estas liberdades sejam desiguais, o que pode admitir o incremento da liberdade substancial dos que têm menos, sem restringir a liberdade daqueles que a detêm de modo mais significativo. No entanto, Rawls reconhece que há também exceções para a limitação da liberdade, segundo contingências históricas ou sociais ou ainda acidentes naturais da vida humana, mesmo em uma sociedade bem ordenada. Segundo exemplos citados pelo autor, as contingências históricas ou sociais que admitiriam a limitação da liberdade dos cidadãos seriam restrições a liberdade de participação e associação admissíveis em momentos de guerras, por exemplo; em se tratando dos acidentes naturais, o autor cita o caso das crianças, que, por sua própria condição, dispõe de liberdade inferior se comparadas aos adultos. A solução mais justa, obviamente, não está na restrição da liberdade dos adultos, mas em se encontrar meios de atender às limitações ínsitas à infância.

Embora Rawls admita a especial importância que dispõe o primeiro princípio em sua teoria, o autor aduz com o segundo princípio que a existência de desigualdades econômicas e de autoridade somente poderá ser considerada justa se for recompensadora para todos os membros da sociedade, em especial aos mais desfavorecidos por aquela desigualdade. Em outras palavras, é bastante normal a existência de diferenças na distribuição de renda e riquezas e na estruturação de organizações que dispõem, cada uma a seu modo, de diferenças de autoridade e responsabilidade. Enquanto os cargos de autoridade devem ser acessíveis a todos os membros da comunidade, Rawls comenta que não existe a necessidade da distribuição de riqueza ser perfeitamente igual entre os cidadãos, desde que seja vantajoso a todos. Este princípio deve estar em sintonia tanto com o primeiro - liberdades fundamentais - como com a igualdade de oportunidades. O critério de justiça para Rawls, a partir desta relação entre os princípios, seria a sua distribuição uniforme na sociedade, a não ser que qualquer desigualdade seja mais vantajosa. Neste sentido, a "injustiça se constitui, então, simplesmente de desigualdades que não são vantajosas para todos" (RAWLS, 2008, p. 75).

Consoante sua presunção, portanto, todos os que estivessem por trás do véu da ignorância escolheriam estes dois princípios. Primeiro a liberdade pois, não tendo qualquer conhecimento sobre a sua situação real ou o

\footnotetext{
22 Rawls publicou a primeira edição de seu livro Teoria da Justiça em 1971, no auge da divisão política do mundo entre o capitalismo e o socialismo. Deste modo, não poderia deixar de reconhecer ambas as parcelas de direitos em sua teoria.

${ }^{23}$ Segundo Rawls (2008, P. 74-75), tratando sobre os dois princípios de justiça como equidade, "esses princípios devem ser dispostos em uma ordem serial, o primeiro sendo prioritário do segundo. Essa ordenação significa que as violações das iguais liberdades fundamentais protegidas pelo primeiro princípio não podem ser justificadas nem compensadas por maiores vantagens sociais e econômicas. Essas liberdades têm um âmbito principal de aplicação, dentro do qual só é possível limitá-las ou comprometê-las quando entram em conflito com outras liberdades fundamentais. Já que podem ser limitadas quando se chocam vol.09, nº. 04, Rio de Janeiro, 2016. pp. 1865-1892 1888
} 
local que estariam no seio da sociedade, dariam preferência a ela como um instrumento mais adequado na persecução de seus objetivos e idéias. Em outra análise, uma vez que o véu da ignorância impede qualquer conhecimento prévio e barra todas as formas de articulações predeterminadas, seria escolhido o segundo princípio como uma forma de minimizar os efeitos no caso de se estar em um nível social inferior. Em ambos os casos, restaria, portanto, a solução menos pior no quadro de possibilidades possível dada a cada pessoa. Rawls aposta no olhar individual e autoprotetor que cada pessoa cultiva dentro de si: sua presunção seria que, sem ser possível o diálogo com outras pessoas, o individualismo prevaleceria para a escolha do fundamento de justiça social, enunciando uma melhor e uma pior hipótese.

Para explicitar de modo mais ilustrativo esta assertiva da justiça procedimental, o jurista trabalha com uma analogia sobre a divisão de um bolo. Supondo que um indivíduo tem o encargo de repartir um bolo entre um determinado número de pessoas, como se daria esta divisão? Se aquela pessoa que tem o encargo de cortar o bolo for alguém egoísta e souber que ficará com a última fatia, é possível que entregue fatias iguais a todos os outros para que reste um pedaço maior para si ao final; ao contrário, se souber que a última não será sua, é possível que corte pedaços maiores e a última fique menor. Em um quadro contrário, se o cortador do bolo for alguém altruísta, é possível que corte o bolo em parcelas iguais ou até mesmo em fatias maiores de modo a oferecer sua parcela a todos. Imperioso notar o grau de importância que Rawls confere ao conhecimento prévio: todas as hipóteses são completamente distintas entre si graças a este aspecto.

A despeito destas considerações, Rawls não quer que o egoísta seja denunciado ou o altruísta seja alçado como um messias a ser seguido por ter pensado mais nos outros do que em si: a questão básica é o modo de assegurar que as fatias sejam idênticas, não apenas parecidas entre si. Nas palavras de Rawls (2008, p. 103-104), "o essencial é que existe um critério independente para se decidir qual resultado é justo e um método que com certeza leve a ele". Sua aposta está no véu da ignorância: tanto o egoísta como o altruísta ou qualquer que seja o traço psicológico daquele que corta o bolo serão convencidos a lhe repartir em pedaços semelhantes se não possuírem nenhum tipo de conhecimento prévio acerca de qual fatia caberá a cada um. Obviamente, Rawls não está preocupado com a divisão de um bolo em si, mas se trata de uma analogia que aponta para a divisão de recursos estatais e a escolha de políticas governamentais. Se forem eleitos princípios na condição indicada, supostamente há uma chance razoável de que os governos se aparelhem de um modo mais isonômico e a sociedade siga este padrão, garantindo melhores resultados a todos. Em termos mais precisos, garantiria uma sociedade mais justa.

Deste modo, na visão de John Rawls, o véu da ignorância é um meio hábil para a escolha dos princípios de justiça. Neste caso, o autor supõe que na posição original, os indivíduos escolheriam os dois princípios 
apontados, que sempre teriam de favorecer a população como um todo, mesmo os mais desafortunados. Este seria o critério isonômico para a justiça. Assim, a justiça como equidade se fundaria em um procedimento racional para a tomada de decisões coletivas, de modo que a sociedade seria erigida com o paulatino combate das intrínsecas desigualdades que a permeiam. Consoante mencionado, Rawls se considera um autor contratual, não no aspecto de fundação, mas na reformulação das sociedades democráticas já existentes, tendo como instrumento a sua teoria da justiça.

Esta hipótese se daria pela decantação das instituições aos princípios de justiça escolhidos pelos membros da comunidade (aqui estaria presente o equilíbrio reflexivo): o critério de justiça seria encontrado na maior ou na mais perfeita proximidade com tais princípios, devendo-se repensar as organizações fundadas em opções distintas às eleitas pela sociedade.

\section{CONSIDERAÇÕES FINAIS}

O contrato social - inserido na teoria de autores do talante de Thomas Hobbes, John Locke e John Rawls - tem a função precípua de servir como um elemento hipotético-justificativo. Esta é sua idéia essencial, na qual se evidencia a necessidade de pautar as relações sociais e políticas no direito (instrumento de racionalização política) ou de ter o pacto como condição formal de existência jurídica do Estado. Nesta toada, cada período the reserva uma finalidade própria, não havendo um conceito definitivo.

Os autores do período clássico do contratualismo o utilizavam como um fator de legitimação ao próprio Estado moderno ainda em gestação. O elemento do contrato na visão de Hobbes e Locke contém o gérmen do Estado de Direito responsável pelo rompimento com o Antigo Regime, no qual conservava em funcionamento o absolutismo. Cada um a seu modo, ambos os autores enunciaram a valia da legalidade como o critério para a justificação desta nova forma de pensar a ordem política e jurídica.

Pode-se inserir a proposta de Rawls como uma continuidade do projeto contratual: não é sua intenção fundar um novo Estado, mas lhe aperfeiçoar de acordo com as instituições existentes. Para tanto, o autor busca reordenar a finalidade do Estado de modo a garantir a justiça de um modo mais isonômico. Assim, não despojando parte do acervo de Hobbes e Locke, mas se valendo do véu da ignorância e do equilíbrio reflexivo, sua teoria pretende lançar os dois princípios de justiça como alicerces deste Estado do pós-guerra.

A teoria destes autores é importante no contexto atual em que o Estado está sempre em busca de sua própria legitimidade. A proposta contratual e neocontratual aponta para a afirmação de segmentos deste Estado que ainda estão em formação, como, por exemplo, a realidade de muitos países em que não há ainda uma consciente e precisa divisão entre o público e o privado. Por esta razão, o projeto da modernidade estatal não está 
consolidado, a despeito de alguns autores crerem que a pós-modernidade já é uma realidade.

FROM THE FOUNDATION OF THE STATE TO THE SEARCH FOR JUSTICE: THE CONTRACTUAL AND NEOCONTRATUAL THEORY

\begin{abstract}
The present issue has the objective to settle down a relation between the theories of Thomas Hobbes, John Locke and John Rawls. Asundered by centuries, these authors share the defense of social contract theory. The contractualism, in vintage and contemporaneous slope, means to legitimate a particular understanding of State and justification of a content. Sharing the essence of social contract theory, this article intents to demonstrate the details of each thinker by his most notorious book (Leviathan, Two Treatises of Government and A Theory of Justice), in such a way to cooperate with the research in law and philosophy.
\end{abstract}

Keywords: Contractualism. Neocontractualism. Leviathan. Two treaties on civil government. A theory of justice.

\title{
REFERÊNCIAS
}

ABBAGNANO, Nicola. Dicionário de Filosofia. São Paulo: Martins Fontes, 2007.

BOBBIO, Norberto; MATTEUCCI, Nicola; GIANFRANCO, Pasquino. Dicionário de Política. 11 ed. Brasília: UNB, 1998.

Norberto. Thomas Hobbes. Rio de Janeiro: Campus, 1991.

CHÂTELET, François; DUHAMEL, Olivier; PISIER-KOUCHNER, Evelyne. História das Idéias Políticas. 2 ed. Rio de Janeiro: Jorge Zahar, 2009.

FASSO, Guido. Storia Della Filosofia del Diritto: L'Età Moderna. Roma: Laterza, 2012.

GOYARD-FABRE, Simone. John Locke Et La Raison Raisonnable. Paris: Librairie Philosophique J. VRIN, 1986.

HOBBES, Thomas. Leviatã. São Paulo: Nova Cultural, 1997. (Os Pensadores)

LOCKE, John. Dois Tratados Sobre o Governo. São Paulo: Abril Cultural, 1973 (Os Pensadores).

Dois Tratados Sobre o Governo. 2a ed. São Paulo: Martins Fontes, 2005.

MARTINS, Marcelo Bueno. Medo e Liberdade no Pensamento de Thomas Hobbes. Primus Vitam Mackenzie. São Paulo. N. 1: p. 1-11, 2010.

MARUYAMA, Natalia. Liberdade, Lei Natural e Direito Natural em Hobbes: Limiar do Direito e da Política na Modernidade. Trans/Form/Ação, São Paulo. N. 32(2): p. 45-62, 2009.

MORRISON, Wayne. Filosofia do Direito: dos Gregos ao Pós-Modernismo. São Paulo: Martins Fontes, 2006. 
RAWLS, John. Conferência sobre a História da Filosofia Política. São Paulo: Martins Fontes, 2012. Uma Teoria da Justiça. 3 ed. São Paulo: Martins Fontes, 2008.

SILVEIRA, Denis Coitinho. Posição original e equilíbrio reflexivo em John Rawls: o problema da justificação. Trans/Form/Ação, São Paulo, 32(1): p. 139-157, 2009.

WERLE, Denilson Luis. O liberalismo contemporâneo e seus críticos. In Manual de Filosofia Política. 2 ed. São Paulo: Saraiva, 2015.

Trabalho enviado em 18 de fevereiro de 2016. Aceito em 02 de junho de 2016. 